\title{
Female Entrepreneurship: The Case of Malian Women
}

\author{
Sedat Aybar ${ }^{1}$ \\ Oumou Keita ${ }^{2}$
}

\begin{abstract}
The study set to assess the female entrepreneurship in Mali focusing on factors that affect the women Entrepreneurship in Bamako Mali. The study objectives were to establish the effect of skills-based training on female entrepreneurship in Bamako Mali, to determine the effect of financial system influence on female entrepreneurship, to assess the effect of market information influence on female entrepreneurship and finally to examine the effect of technological advancement on female entrepreneurship in Bamako Mali. The study employed a descriptive research design based on regression analysis; the study used questionnaires attained from 334 respondents who were women in Bamako holding businesses. Skills based training, financial system, market information and technology advancement have a significant effect on women enterprises. The study concludes that skills-based training has a significant effect on female entrepreneurship in Bamako Mali indicating that the presence of female entrepreneurs' skills if improved is an icon for female businesses support. Secondly, the study concludes that the financial system influences female entrepreneurship. The study concludes that developing a financial system for the females in Mali can generate effective business growth for the females in Mali. Thirdly the study concludes that there is less access to market information, most existing networks are male dominated and difficult for women to access. Finally, the study conclude that the technology advancement was not significant in women businesses. The study recommend for government and non-government organizations should start focusing on cluster development in entrepreneurship based on the natural resource availability.
\end{abstract}

${ }^{1}$ Prof. Dr. İstanbul Aydın University, Department of Economics and Finance, sedataybar@aydin.edu.tr, Orcid: 0000-0002-2544-4332.

${ }^{2}$ Istanbul Aydın University, Graduate Student in Business Administration, oumoukeita@stu.aydin.edu.tr, Orcid: 0000-0001-6021-8974.

*Research Article. Received: 02.08.2021, Accepted: 12.08.2021.

DOI: 10.17932/IAU.FCPE.2015.010/fcpe_v07i2001

Florya Chronicles of Political Economy - Year 7 Number 2 - October 2021 (83 -103) 
This policy must keep a provision of collateral free loan, credit without interest or low rate of interest, loan for long time duration for Female entrepreneurs. There is further need for enhancing marketing schemes by either woman forming organizations that can support market research and attainment of market environment information sufficient for their businesses.

Key words: Female entrepreneurship, business growth, Mali. 


\section{INTRODUCTION}

\section{Background to the Study}

The study investigated the Female Entrepreneurship: Malian women acting Entrepreneurial.

Female Entrepreneurship is a tendance that is considered in the growth of the proportion in the choice of the start in consideration in the growth for the management in the businesses (Mekonnen and Castino, 2017). The instances for the means in global entrepreneurship rates in the rise across the world for the recent decades and has a high effect on the continent (GEM, 2016). The entrepreneurship function is a contribution to progress in acknowledgement that is still in special sub-Saharan Africa and women Entrepreneurs in the necessity for the study (GEM, 2017).

Globally, businesses monitor reporting that the women Entrepreneurs earn jobs, wealth, and innovations at the 37 countries that were surveyed. The countries are rated in growth among the ones in creation of the businesses that are of growth in Entrepreneurs (Shinnar, Giacomin and Janssen, 2012). Women's Business Research, World Bank (2008) contend that close to 10.4 million US organizations are under ownership of the women employing more than $12.8 \%$ million people and attract the 1.9 trillion dollars as sales. The growth rate for the women owned firms has been $42 \%$ in comparison to $24 \%$ of the companies in the United States of America.

In Africa, women businesses are of development mix in the recent emergence of the lays in emphasizing that the economic values for the women participate. Close to $35 \%$ of the households in worldwide form of women and participated in the labor force provided in the countries and a comparison of the increase in proportion in formal sector activities in the developing countries in the world. In Kenya, more than $32 \%$ of households are headed by women (Sullivan and Meek, 2012), the many were starting to venture in the same form of the scales of activities needed in self-employment activities (Uy, Foo and Song, 2013).

Mali presents a status of women situation that limit entrepreneurial development amongst women. The inspirations for the seen in various development initiatives encouraging the people in expansion in the learning for absorption of the entrepreneurship minds in the tools for practice (Vanuytsel and Ceppens, 2019). Entrepreneurship training provision in 
the government in space that are exposed in connection to the NGOS and private initiative resulting in greater in the success. The abilities in the Entrepreneurs in obtaining loans in Bamako is of extreme restriction in the bank unwillingness in the business in corruption surrounding being assessed for the loan in final interest in making borrows in thus realization plans.

\section{Statement of the Problem}

Women constitute almost fifty percent of the world population. The socio-economic participation of women at the international, regional, national, and local levels means using significant potential resources more effectively (Kelley, Baumer, Brush, Greene, Madhavi and Marcia, 2017). Though women in Mali have undertaken Entrepreneurship development, majority of the women in Mali do not possess any assets and cannot formally offer the necessary securities against loans (AfDB, 2019). Due to the complexities in the social environment and administrative structure, women's entrepreneurship in Mali is more challenging skills-based training, financial system influence, market information and technological advancement are pivotal in influencing the female entrepreneurship (Fatouma, 2019). It is incumbent to this that the research on female entrepreneurship in the context of Mali is conducted to establish the status quo and provide remedies to improving the status quo.

\section{Objectives of the Study}

1)To establish the effect of skills-based training on female entrepreneurship in Bamako Mali

2)To determine the effect of financial system influence on female entrepreneurship in Bamako Mali

3)To assess the effect of market information influence on female entrepreneurship in Bamako Mali

4)To examine the effect of technological advancement on female entrepreneurship in Bamako Mali

\section{Significance of Study}

For academicians and researchers, they would do an in-depth investigation on the effect of female entrepreneurship in social development projects in 
Mali. The research will help in building an understanding on the regulation and the recommendations that are applicable in the necessary for the social development in the business management. The research will assess the process that will provide information on measures for the developed in addressing the challenges that affect the increases and declines in female entrepreneurs.

Figure 1: Factors Affecting and Female Entrepreneurship

\section{Conceptual Framework}

Factors affecting

- Skills based training.

- Financial system influence

- Market information

- Technological advancement
Female Entrepreneurship

Women Entrepreneurship

The framework predicts the factors that influence/ have a bearing on female Entrepreneurship. The study predicts that female entrepreneurship has been affected by skills-based training, financial system influence, market information and technological advancement that is pivotal in influencing the female entrepreneurship development or slowing the development of the businesses in the women environment.

\section{Definitions of Key Terms}

Woman entrepreneur, A woman entrepreneur is the woman who does business management in the process of the capital for setting up scale enterprise and active involvement in management of the businesses in the areas of management and earning the livelihoods for the families that are of business nature belonging to the incomes.

Financial system is key in implementation of procedures that are tracking the financial activities for the company. The regional scale financial systems for systems in enables lending and borrowing for exchanging funds. 
Technology advancement, A technological advance is a situation in which resources are combined in such a way that the same volume of resources results in greater output or a lesser number of resources creates the same output as before.

Market information, The market research is used in planning for the future marketing in product development activities where information comes from single sources in the systems of Collections.

\section{Literature Review}

The chapter intended to present the theories and empirical review, knowledge, and information necessary information to the study of the themes in the research. The research provides the chapters focusing on the reviews by different scholars on female entrepreneurship.

\section{Skills Based Training on Female Entrepreneurship}

Katerina L S, et al (2010) did a study on entrepreneurship training for the women in the attainment of innovations needed for the case of development. The study reveals that the 1 hundred and sixteen information from businesses are attained in the form of small and medium enterprises for the information collected through questionnaires in collection of the data in cross tabulations and verification of the data needed. The study shows that businesses owned by the SMEs and managers are provided in the small businesses needed for the people in Grece and providing the forms of creativity and innovations.

\section{Financial System Influence on Female Entrepreneurship}

Mariam (2013) shows that capital access in strategic and business growth is selected for the women businesses in Sokot Metropolis, the findings show that there is a positive connection between capital access and business growth. The women entrepreneurs/ businesses are a source of capital for the many savings that are of the reason in the business growth or failures. Government has hence provided a strong effect in achieving the business values. it was found that governance has a key effect on attainment of the business.

Leonard (2013) contends that women lack assets because of the gender discrimination generally aimed at inheritances in practice for the countries that hinder access for the resource's controls. 
The author provides that access for the controls in resources has a negative effect on women businesses, for instance, Leonard (2013) provided that female headed business in the claim for inability for saving the capital that prevent them in business engagement.

Jandeska \& Kraimer (2015) provided that the assessment for the effect of microfinance industries that become the global situation. The study examines the financial products aimed for the women businesses and call for the products in saving the account, in money transfer loans for the domestic equipments needed.

\section{Market Information Influence on Female Entrepreneurship}

Nosa (2013) contends that women businesses are of own basis and small and medium enterprises are of complain in the lack of demand for the products due to the issues of responses increased in markets. The factors needed to limit the women incomes generated in activities that can provide the access for the markets.

The state of inexperienced form of the entrepreneurs is a liked form for dependence in the advice for the close friends that are somehow known and trusted and friend that provide offers in opportunities for the resources that affect the businesses for the women. Small businesses are relying on the advice for the people in relative forms for the orders in the maintenance of the confidential controls for the business's environments for the avenues in the study management determined.

Sandberg (2013) contends that women business mentors need to be confident in the skills for the service that is good for the mentors needs in the models for women in businesses (Kickul \& Gundry, 2006). Technological Advancement on Female Entrepreneurship

Jain (2006) provided that the prevalence of ICT provides a key aspect in the form of information necessary for the women in small and medium businesses. It's for instance an aspect for the use of phones to show how technology can be manipulated to value the women lives by saving the travels and connection between the markets and suppliers which allow women to ask for the product prices and add the facilities for the constant judge provided in the family activities. The use of ICT is connected to the effect of women having the limited access in the roads and credit for the 
development. ICT needs to have some skills and assume that the provision of the facilities is key, and every community has an immediate embracing of the technologies.

Hafkin and Taggart (2001) started that the communication, transportation and issues that hinder development of ICT is good for the women in development where the development is provided in the world that have access for the abundance in alternatives. The need for great concentration is hence an aspect for the people in villages that women are of gender sensitivity empowering the people in Nigeria and Ethiopia local government in the instance the global scale becoming positive in the world and promotion of the gender equity for the women activities to reduce the poverty, hunger, diseases in a mode for stimulation in development for the truly sustainable for ensuring the values in technology and information for the communicating technology needed in available forms.

\section{METHODOLOGY}

\section{Research Design}

The study employed a descriptive research design. The descriptive research design was employed to determine the existence of women Entrepreneurship in Mali based in Bamako assessing the influence of factors on the women businesses. The study was quantitative based on closed ended questionnaires that solicited information from women Entrepreneurship. The design is deemed fit since it enables the attainment of the data needed for assessing the degree of the effect presented on women entrepreneurship.

\section{Population of the Study}

The study targeted these women in the bid to establish the state of their existence in Bamako- in a bid to assess the female Entrepreneurship situation in Bamako. The sample Population for the study was 379. The data was collected from 334 respondents who responded or provide back the questionnaire who were female business owners. 


\section{Sample Selection}

The study employed stratified and random sampling technique was used to collect quantitative data from the respondents. Stratified Sampling was used to obtain data from the staff from the different strata categories where the central business district was stratified into different categories, they're after simple random sampling was used in the selection of women in this strata areas.

\section{Data Collection Instrument (Questionnaires)}

Questionnaires are questions designed by the researcher and given to the respondents to have them filled. Questionnaires were designed based three sections, section $\mathrm{A}=$ Demography of respondents, section $\mathrm{B}$, questionnaire on factors influencing Entrepreneurship of women such as skills-based training, financial system influence, technological advancement and market information influence and section $\mathrm{C}=$ on status of female Entrepreneurship.

\section{Data Analysis}

After the collection for the data, information was compiled, sorted, edited and coded to have a required form of quality accuracy and completed forms. The study used SPSS version 22 to analyze the data which was done descriptively using frequency and percentages and mean and standard deviation and thereafter the mean and standard deviation was done to present information on the degree of how the factors influencing Entrepreneurship of women such as skills based training, financial system influence, technological advancement and market information influence and section and status of female Entrepreneurship. Still, data analysis was carried out following the study objectives whereby data on objective one, two and three and fourth objective was analyzed using simple regression analysis to attain the degree and nature of effect between factor influence and status of female Entrepreneurship in Bamako Mali.

This chapter presents the findings from the study with specific emphasis on examining the effect of female entrepreneurship in Mali focusing on factors that affect the women Entrepreneurship in Bamako Mali. The data was collected 334 respondents who provided information through the use of questionnaires 
Table 1: Demography of Respondents

\begin{tabular}{|c|c|c|}
\hline Gender & Frequency & Percent \\
\hline Male & 228 & 68.3 \\
\hline Female & 106 & 31.7 \\
\hline \multicolumn{3}{|l|}{ Education } \\
\hline Primary and secondary & 119 & 35.6 \\
\hline Diploma & 40 & 12.0 \\
\hline Degree & 92 & 27.5 \\
\hline others & 83 & 24.9 \\
\hline \multicolumn{3}{|l|}{ Age } \\
\hline Below 20 Years & 12 & 3.6 \\
\hline $20-30$ & 51 & 15.3 \\
\hline $30-40$ & 99 & 29.6 \\
\hline $40-50$ & 100 & 29.9 \\
\hline $50+$ & 72 & 21.6 \\
\hline \multicolumn{3}{|l|}{ Time } \\
\hline Less than 5 years & 87 & 26.0 \\
\hline 6-10years & 51 & 15.3 \\
\hline $10-14$ years & 114 & 34.1 \\
\hline 15 Years above & 82 & 24.6 \\
\hline Total & 334 & 100.0 \\
\hline
\end{tabular}

Source: Primary Data, 2021 
Data presented in the table 1.1 on the gender for the respondents revealed that many of the respondents were male who were $68.3 \%$ of the study, female were $31.7 \%$ of the study. The study results reveal that majority of the respondents were primary and secondary school leavers constituting $35.6 \%$ of the respondents followed by degrees with $27.5 \%$, other qualifications who included post graduate and professional qualifications were $24.9 \%$ while diploma holders were $12 \%$. The study findings reveal that majority respondents were in the age of 40 to 50 with $29.9 \%$ followed by $30-40$ with $29.6 \%$ respondents, 50 years above had $21.6 \%$ respondents while for 20-30 years had $15.3 \%$ and those of below 20 but above 18 years were $3.6 \%$ respondents finally on the time of stay in Bamako, The study results indicate that majority respondents had been in Bamako for a period of $10-14$ years for $34.1 \%$, followed by those of less than 5 years were $26 \%$, those of $6-10$ years were $15.3 \%$ and finally, those with more than 15 years were $24.6 \%$ of the respondents.

\section{Effect of Skills-Based Training on Female Entrepreneurship in Bamako Mali}

The first objective of the study was to establish the effect of skills-based training on female entrepreneurship in Bamako Mali. To attain the effect the researcher used simple regression analysis to establish the effect between skills-based training on female entrepreneurship in Bamako Mali. 
Table 2: Regression Analysis on Effect of Skills-Basedttraining on Female Entrepreneurship in Bamako Mali

\begin{tabular}{|c|c|c|c|c|c|c|c|}
\hline \multicolumn{8}{|c|}{ Model Summary } \\
\hline Model & \multicolumn{2}{|l|}{$\mathrm{R}$} & R Square & $\begin{array}{l}\text { Adjusted } \\
\text { R Square }\end{array}$ & \multicolumn{3}{|c|}{$\begin{array}{l}\text { Std. Error of the } \\
\text { Estimate }\end{array}$} \\
\hline 1 & \multicolumn{2}{|l|}{$.121^{\mathrm{a}}$} & .015 & .012 & \multicolumn{3}{|c|}{.54739} \\
\hline \multicolumn{8}{|c|}{ a. Predictors: (Constant), Skills based training } \\
\hline \multicolumn{8}{|c|}{ ANOVA $^{\mathbf{a}}$} \\
\hline \multicolumn{2}{|c|}{ Model } & $\begin{array}{l}\text { Sum of } \\
\text { Squares }\end{array}$ & $\mathrm{df}$ & $\begin{array}{l}\text { Mean } \\
\text { Square }\end{array}$ & \multicolumn{2}{|l|}{$\mathrm{F}$} & Sig. \\
\hline \multirow[t]{3}{*}{1} & Regression & 1.488 & 1 & 1.488 & \multicolumn{2}{|c|}{4.965} & $.027^{\mathrm{b}}$ \\
\hline & Residual & 99.480 & 332 & .300 & & & \\
\hline & Total & 100.967 & 333 & & & & \\
\hline \multicolumn{8}{|c|}{ a. Dependent Variable: Female entrepreneurship } \\
\hline \multicolumn{8}{|c|}{ b. Predictors: (Constant), Skills based training } \\
\hline \multicolumn{8}{|c|}{ Coefficients $^{a}$} \\
\hline \multirow[t]{2}{*}{ Model } & & \multicolumn{2}{|c|}{$\begin{array}{l}\text { Unstandardized } \\
\text { Coefficients }\end{array}$} & \multirow{2}{*}{\multicolumn{2}{|c|}{$\begin{array}{l}\text { Standardized } \\
\text { Coefficients } \\
\text { Beta }\end{array}$}} & \multirow[t]{2}{*}{$\mathrm{t}$} & \multirow[t]{2}{*}{ Sig. } \\
\hline & & $\mathrm{B}$ & Std. Error & & & & \\
\hline \multirow[t]{2}{*}{1} & (Constant) & 2.826 & \multicolumn{3}{|l|}{.141} & 20.107 & .000 \\
\hline & $\begin{array}{l}\text { Skills based } \\
\text { training }\end{array}$ & .117 & .052 & .121 & & 2.228 & .027 \\
\hline
\end{tabular}

Source: Primary Data, 2020

Regression analysis on effect of skills-based training on female entrepreneurship in Bamako Mali reveal that the r-value of .121 was attained indicating that skills based training contribute $12.1 \%$ effect on female entrepreneurship in Bamako Mali, the rest is contributed by other factors other than skills training. The standard error of .54739 indicates the closeness of data.

In the analysis of the variance for the study the significance value was $.027^{\mathrm{b}}$ indicating that there is a significant effect of skills based training on female entrepreneurship in Bamako Mali implying that the status of the skills based training induce the entrepreneurship meaning that improved skills based training highly affect the female entrepreneurship.

The coefficients for the independent variable (skills-based training) were in acceptable ranges to support the relevance in the model where it had a 
computed t value for 2.228, which was more than 1 and significant value of 0.027 less than 0.05 that implies that skills-based training contribute significantly to female entrepreneurship in Bamako Mali. It worths arguing that improvement of the skills-based training is an avenue that can enhance the female entrepreneurship

\section{Effect of Financial System Influence on Female Entrepreneurship in Bamako Mali}

The second objective was to determine the effect of financial system influence on female entrepreneurship in Bamako Mali. To attain the effect the researcher used simple regression analysis to establish the effect of financial system influence on female entrepreneurship in Bamako Mali.

Table 3: Effect of Financial System Influence on Female Entrepreneurship in Bamako Mali

\begin{tabular}{|c|c|c|c|c|c|c|c|c|c|}
\hline \multicolumn{10}{|c|}{ Model Summary } \\
\hline \multicolumn{2}{|c|}{ Model } & $\mathrm{R}$ & \multicolumn{2}{|c|}{ R Square } & \multicolumn{2}{|c|}{ Adjusted R Square } & \multicolumn{3}{|c|}{ Std. Error of the Estimate } \\
\hline \multicolumn{2}{|c|}{1} & $.208^{\mathrm{a}}$ & \multicolumn{2}{|c|}{.043} & \multicolumn{2}{|l|}{.040} & \multicolumn{3}{|l|}{.53945} \\
\hline \multicolumn{10}{|c|}{ a. Predictors: (Constant), Financial system influence } \\
\hline \multicolumn{10}{|c|}{ ANOVA $^{a}$} \\
\hline \multicolumn{3}{|c|}{ Model } & \multicolumn{2}{|c|}{$\begin{array}{l}\text { Sum of } \\
\text { Squares }\end{array}$} & $\mathrm{df}$ & $\begin{array}{l}\text { Mean } \\
\text { Square }\end{array}$ & $\mathrm{F}$ & \multicolumn{2}{|l|}{ Sig. } \\
\hline \multirow[t]{3}{*}{1} & \multicolumn{2}{|c|}{ Regression } & \multicolumn{2}{|c|}{4.352} & 1 & 4.352 & 14.954 & \multicolumn{2}{|l|}{$.000^{\mathrm{b}}$} \\
\hline & \multicolumn{2}{|c|}{ Residual } & \multicolumn{2}{|c|}{96.616} & 332 & .291 & & & \\
\hline & \multicolumn{2}{|c|}{ Total } & \multicolumn{2}{|c|}{100.967} & 333 & & & & \\
\hline \multicolumn{10}{|c|}{ a. Dependent Variable: Female entrepreneurship } \\
\hline \multicolumn{10}{|c|}{ b. Predictors: (Constant), Financial system influence } \\
\hline \multicolumn{10}{|c|}{ Coefficients $^{\mathrm{a}}$} \\
\hline \multirow{2}{*}{\multicolumn{4}{|c|}{ Model }} & \multicolumn{3}{|c|}{$\begin{array}{l}\text { Unstandardized } \\
\text { Coefficients }\end{array}$} & $\begin{array}{l}\text { Standardized } \\
\text { Coefficients }\end{array}$ & \begin{tabular}{l|l}
$d$ & $t$ \\
\end{tabular} & Sig. \\
\hline & & & & \multicolumn{2}{|l|}{ B } & $\begin{array}{l}\text { Std. } \\
\text { Error }\end{array}$ & Beta & & \\
\hline \multirow[t]{2}{*}{1} & \multicolumn{3}{|c|}{ (Constant) } & \multicolumn{2}{|c|}{3.611} & .127 & & 28.373 & .000 \\
\hline & \multicolumn{3}{|c|}{$\begin{array}{l}\text { Financial system } \\
\text { influence }\end{array}$} & \multicolumn{2}{|l|}{.198} & .051 & .208 & 3.867 & .000 \\
\hline \multicolumn{10}{|c|}{ a. Dependent Variable: Female entrepreneurship } \\
\hline
\end{tabular}

Source: Primary Data, 2020 
Regression analysis on effect of financial system influence on female entrepreneurship in Bamako Mali reveals that the r-value of $.208^{\text {a }}$ was attained indicating that financial system influence has a $20.8 \%$ effect on female entrepreneurship in Bamako Mali. The standard error of .53945 indicates the closeness of data.

In the analysis of the variance for the study the significance value was $.000^{\mathrm{b}}$ indicating that there is a significant effect of financial system influence on female entrepreneurship in Bamako Mali implying that the status of financial system influence induces the entrepreneurship.

The coefficients for the independent variable (financial system influence) were in acceptable ranges to support the relevance in the model where it had a computed $t$ value for 3.867 , which was more than 1 and significant value of 0.000 , below 0.05 level of significance that implies financial system influence contribute significantly to female entrepreneurship in Bamako Mali. It is worthy arguing that improvement of the financial system influence is an avenue that can enhance the female entrepreneurship. The study results agree with Mariam Alhabidi (2013) shows that capital access in strategic and business growth is selected for the women businesses in Sokot Metropolis, the findings show that there is a positive connection between capital access and business growth. Even Jandeska \& Kraimer (2015) provided that the assessment for the effect of microfinance industries that become the global situation. The studies examine the financial products aimed for the women businesses and call for the products in saving the account, in money transfer loans for the domestic equipments needed.

\section{Effect of Market Information Influence on Female Entrepreneurship in Bamako Mali}

The third objective of the study was to assess the effect of market information influence on female entrepreneurship in Bamako Mali. Regression analysis on effect of market information influence on female entrepreneurship in Bamako Mali. 
Table 4: Effect of Market Information Influence on

Female Entrepreneurship in Bamako Mali

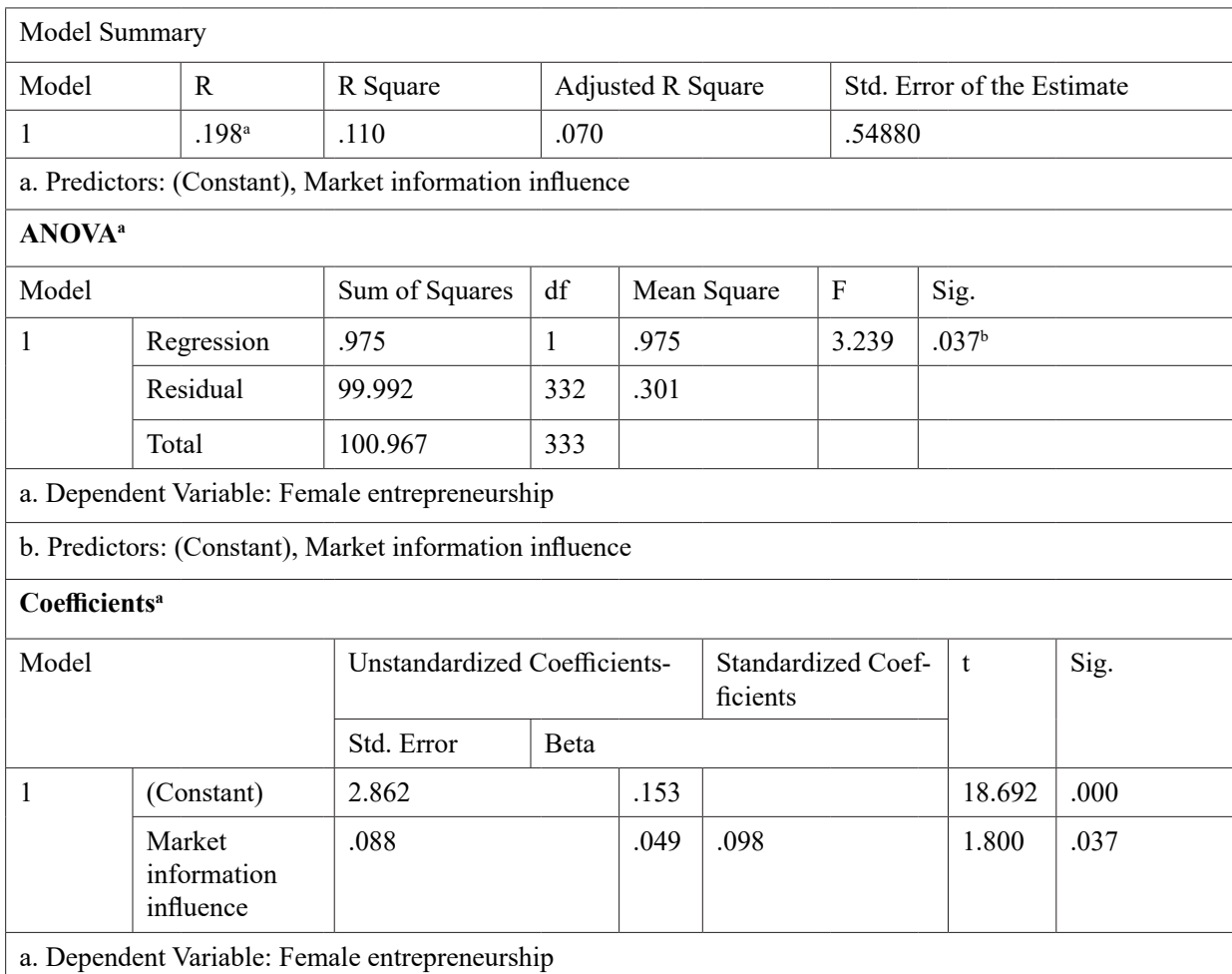

Source: Primary Data, 2020

Regression analysis on effect of Market information influence on female entrepreneurship in Bamako Mali reveals that the r-value of $.198^{\mathrm{a}}$ was attained indicating that market information influence had a $19.8 \%$ effect on female entrepreneurship in Bamako Mali. The standard error of .54880 indicates the closeness of data.

The coefficients for the independent variable (market information influence) was in acceptable ranges to support the relevance in the model where it had a computed $t$ value for 1.800 , which was more than 1 and significant value of 0.037 below the level of significance of 0.005 , that implies that market information influence contribute significantly to female entrepreneurship in Bamako Mali. It's worthy arguing that improvement of the market information access is an avenue that can enhance the female entrepreneurship. In the same notion, Mahbub (2000) provided that a 
network for the issues that affect the women businesses, Having the good networks for the people in the matter key for success in the business lacked for the women businesses.

\section{Effect of Technological Advancement on Female Entrepreneurship in Bamako Mali}

The four objective of the study was to assess the effect technological advancement on female entrepreneurship in Bamako Mali. Regression analysis on effect of technology advancement on female entrepreneurship in Bamako Mali.

Table 5: Effect of Technological Advancement on Female Entrepreneurship in Bamako Mali

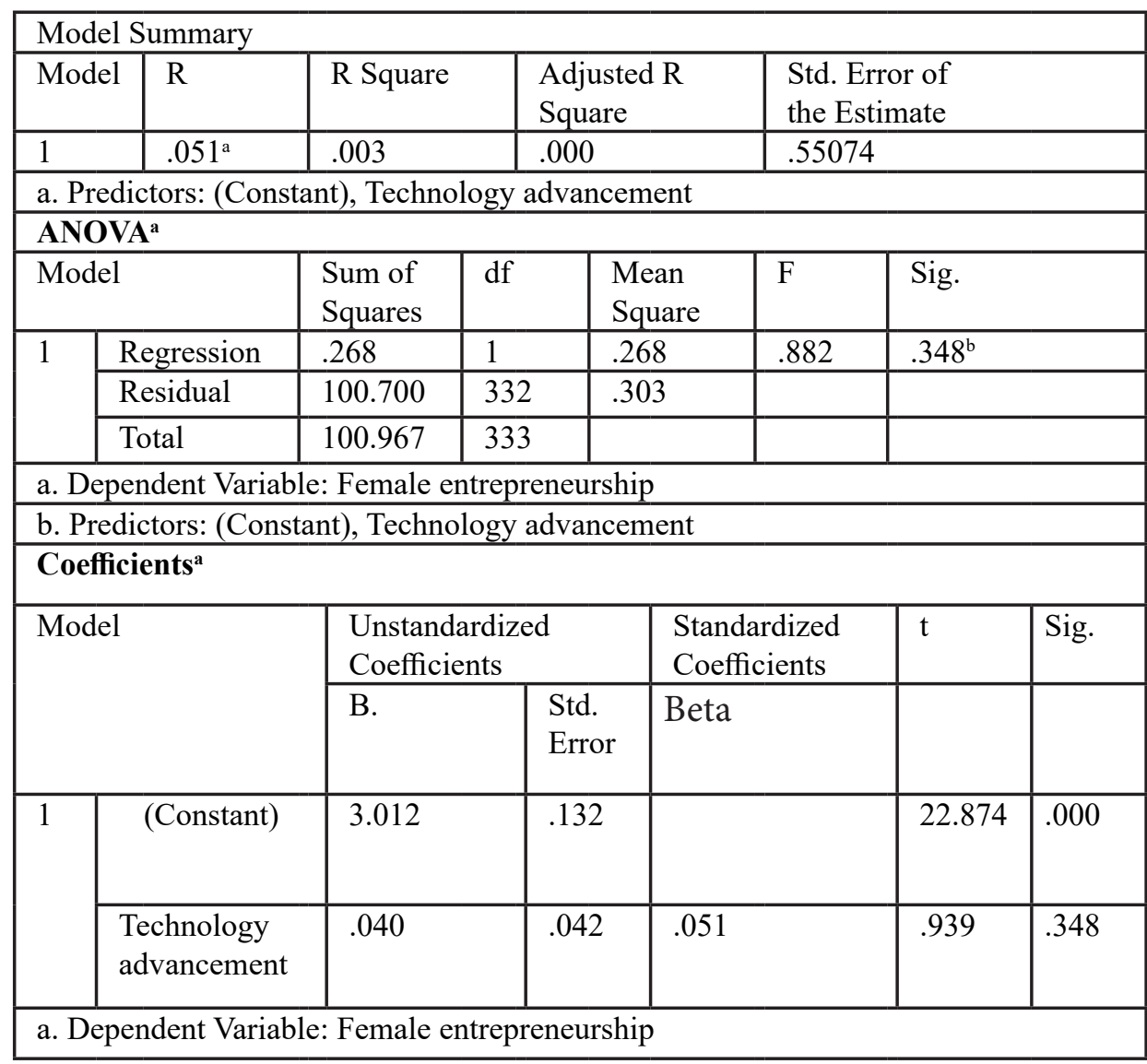

Source: Primary Data, 2020 
Regression analysis on effect of technology advancement on female entrepreneurship in Bamako Mali reveal that the r-value of $.051^{\mathrm{a}}$ was attained indicating that technology advancement has had a $5.1 \%$ effect on female entrepreneurship in Bamako Mali. The standard error of .55074 indicates the closeness of data.

In the analysis of the variance for the study the significance value was $.348^{\mathrm{b}}$ indicating that there is a nonsignificant effect of technology advancement on female entrepreneurship in Bamako Mali implying that technology advancement does not influence induces the entrepreneurship meaning that the technology advancement has been of les value female entrepreneurship in Malian women. The coefficients for the independent variable (technology advancement) were outside acceptable ranges to support the relevance in the model where it had a computed $t$ value for .939 , which was less than 1 and significant value of 0.348 above the 0.005 level of significance that implies that technology advancement has been of les value female entrepreneurship in Malian women. The results are in agreement with Hafkin and Taggart (2001) started that the communication, transportation and issues that hinder development of ICT is good for the women in development where the development is provided in the world that have access for the abundance in alternatives.

\section{Research Hypothesis Testing}

Under this part, the researcher related the results found from the analysis carried out to the hypothesis in Chapter 1.

Hypothesis 1: There is a statistically significant effect of skills-based training on female entrepreneurship in Bamako Mali. Results in table 4.8 on effect of skills-based training on female entrepreneurship in Bamako Mali reveal that the r-value of .121, significance value of 0.027 indicating that skills-based training had a significant effect on female entrepreneurship. The research hypothesis H1: is therefore upheld and there is a statistically significant effect of skills-based training on female entrepreneurship in Bamako Mali.

Hypothesis 2: There is a statistically effect of financial system influence on female entrepreneurship in Bamako Mali: Results in table 4.9 on effect of financial system influence on female entrepreneurship in 
Bamako Mali reveal that the r-value of .208, significance value of 0.000 indicating that financial system influence had a significant effect on female entrepreneurship. The research hypothesis H1: is therefore upheld and there is a statistically significant effect of financial system on female entrepreneurship in Bamako Mali.

Hypothesis 3: There is a statistically effect of market information influence on female entrepreneurship in Bamako Mali. Results in table 4.10 on effect of market information influence on female entrepreneurship in Bamako Mali reveal that the r-value of .198, significance value of 0.037 indicating that market information influence had a significant effect on female entrepreneurship. The research hypothesis H3: is therefore upheld and there is a statistically significant effect of market information influence on female entrepreneurship in Bamako Mali.

Hypothesis 4; There is a statistically effect of technological advancement on female entrepreneurship in Bamako Mali. Results in table 4.11 on effect of technological advancement influence on female entrepreneurship in Bamako Mali reveal that the r-value of .051, significance value of 0.384 . The research hypothesis H4: is therefore rejected and the researchers contend that there is no statistically significant effect of technological advancement influence on female entrepreneurship in Bamako Mali.

\section{CONCLUSION}

The study concludes that skills-based training has a significant effect on female entrepreneurship in Bamako Mali indicating that the presence of female entrepreneurs' skills if improved is an icon for female businesses support, the low training skills have hampered the business management and handling. Secondly, the study concludes that financial system influences female entrepreneurship. The study concludes that developing a financial system for the females in Mali can generate effective business growth for the females in Mali. Thirdly the study concludes that there is less access to market information, most existing networks are male dominated and difficult for women to access. From the findings, the poor networking among women was because of poor feasibility studies and low confidence among them. Finally, the study concludes that the technology advancement was not significant in women businesses, further showing that the status of the technology advancement is less contributing to female business hence the need for adequate consideration in the same. 


\section{RECOMMENDATIONS}

On the first objective of effect of skills-based training on female entrepreneurship in Bamako Mali. Government and non-government organizations should start focusing on cluster development in entrepreneurship based on the natural resource availability. There should be better established links among various organizations who are working for entrepreneurship development and women's empowerment rather than having competition for yearly target achievement amongst themselves.

On the second objective of effect of financial system influence on female entrepreneurship in Bamako Mali. This policy must keep a provision of collateral free loan, credit without interest or low rate of interest, loan for long time duration for Female entrepreneurs.

On the third objective of effect of market information influence on female entrepreneurship in Bamako Mali. There is the urgent need to improve on the existing policies and legal framework in a manner that would practically reach a satisfactory level to encourage the female entrepreneurs. There is further need for enhancing marketing schemes by either woman forming organizations that can support market research and attainment of market environment information sufficient for their businesses.

On the fourth objective of effect of technology advancement influence on female entrepreneurship in Bamako Mali, Female should be encouraged to study Science and Technology in schools and colleges / Universities. With this, they could gain access to know- how, technologies, appropriate and adequate skills, training to upgrade their technical capabilities, and their entrepreneurial skills. Create easy access for Female entrepreneurs to the local administrative support and public institutions. 


\section{REFERENCES}

[1] African Development Banking Group (AfDB). Mali Economic Outlook -Source African Economic Outlook (AEO) 2019. https://inyurl.com/ yxgs6npn

[2] Alhabidi, M. (2013) "Saudi Women Entrepreneur Over Coming Barriers In ALKhober”, Arizona State University.

[3] Fatouma, G. (2019) Interview with Founder and owner of Gie Faouma Aiga Onion processing firm. [In-person interview Bamako, Mali].

[4]GEM.(2016). Global report. Retrieved from http://www.gemconsortium. org/ report.

[5]GEM.(2017). Global report. Retrieved from http://www.gemconsortium. org/ report.

[6] Gundry, L. \& Kickul, J. (2006) "Entrepreneurship Strategy: Changing Patterns in New Venture Creation, Growth, and Reinvention", 1 St Edition, ISBN-13: 978-1412916561, 2006.

[7] Hafkin, N. \& Taggart N. (2001) “Gender, Information Technology, and Developing Countries: An Analytic Study", Academy for Educational Development (AED).

[8] Jain, P. (2006), "Empowering Africa's development using ICT in a knowledge management approach", The Electronic Library, Volume 24, Issue 1.

[9] Jandeska, K. \& Kraimer M. (2015). Women's perceptions of organizational culture, work attitudes, and Journal of Gender Studies, 4 (3), 297-314.

[10] Kelley, D. J., Baumer, B. S., Brush, C., Greene, P. G., Madhavi, M. \& Marcia Cole, M. M (2017) Global entrepreneurship Research Association (GERA). (2017). Global Entrepreneurship, Monitor: Women'sEntrepreneurship2016/2017Reporton, Women's Entrepreneurship. Retrieved from http://www.gemconsortium.org/ report/49812. 
[11] Leonard, E. (2013). "Challenges Faced By Female Entrepreneurs," Journal of International Business, Vol. 4. Pp. 2-4.

[12] Mahbub, U.H. (2000). "Human Development Centre, Human Development in South Asia: The Gender Question” Oxford University Press.

[13] Mekonnen, H. D \& Castino, J. (2017). The impact of institutional context on women's entrepreneurship in Ethiopia: Breaking the cycle of poverty? In M. R. Pasillas, B. Etheland M.

[14] Nosa, U. (2013). "Challenges Faced By Female Entrepreneurs," Journal of International Business, Vol. 11. Pp. 33-34.

[15] Sandberg, S. (2013). "Lean in: Women, work, and the will to lead", American Psychological Association, 2013.

[16] Sarri, K. K., Bakouros, I., Petridou, E. (2010). "Entrepreneur training for creativity and innovation", Journal of European Industrial Training, 2010 .

[17] Shinnar, R. S., Giacomin, O. \& Janssen, F. (2012). Entrepreneurial perceptions and Siba, E. (2016). Enabling female entrepreneurs and beyond. Retrieved from

[18] Sullivan, D. M. \& Meek, W. R. (2012). "Gender and entrepreneurship: A review and process model” Journal of Managerial Psychology, 2012.

[19] Uy, M. A., Foo, M.-D. \& Song, Z. (2013). Joint effects of prior startup experience and coping strategies on entrepreneurs' psychological wellbeing. Journal of Business Venturing, 28(5), 583-597.

[20] Vanuytsel. S. \& Ceppens, F. (2019). Meeting with Beligan Embassy Staff supporting political and economic affairs". [Personal interview].

[21] World Bank (2008). What Are the Constraints to Inclusive Growth in Zambia? Report No.44286-ZM, Washington DC: World Bank.

[22] World Bank (2008). What Are the Constraints to Inclusive Growth in Zambia? Report No. 44286-ZM 